\title{
Makna Simbolik dalam Tradisi Mipit Pare pada Masyarakat Desa Mekarsari Provinsi Jawa Barat
}

\author{
Muzizat Nurul Fauziah ${ }^{1}{ }^{*}$, Fardiah Oktariani Lubis ${ }^{1}$, Ema $^{1}$
}

${ }^{1}$ Universitas Singaperbangsa Karawang, Indonesia

\author{
A R T I C L E I N F O \\ Article history: \\ Received 22 June 2021 \\ Accepted 30 July 2021 \\ Available online 01 \\ December 2021 \\ Kata Kunci: \\ Tradisi Mipit Pare; \\ Makna Simbol; \\ Pelaksanaan Mipit \\ Pare \\ Keywords: \\ Mipit Pare Tradition; \\ Meaning of Symbols; \\ Mipit Pare \\ Implementation
}

\begin{abstract}
A B S T R A K
Banyak masyarakat Desa Mekarsari yang melakukan tradisi Mipit Pare tetapi tidak mengetahui makna simbol dari tradisi tersebut. Penelitian ini difokuskan untuk mengetahui makna simbol dan proses pelaksanaan yang terdapat dalam tradisi Mipit Pare. Penelitian ini menggunakan metode kualitatif dengan pendekatan deskriptif. Teknik pengumpulan data diperoleh dari pengamatan langsung, wawancara serta dokumentasi. Dari hasil penelitian dapat diketahui bahwa, pelaksanaan tradisi Mipit Pare memiliki beberapa tahapan dan masing-masing memiliki makna simbol, diantaranya : Penentuan hari pelaksanaan memiliki makna simbol bahwa dalam menentukan sesuatu harus sesuai dengan kepercayaan yang dianut agar tidak terjadi hal-hal yang tidak diinginkan, sesajen memiliki makna simbol sebagai tanda terimakasih kepada leluhur dan Sanghyang Sri, pembacaan kidung dan membakar kemenyan memiliki makna simbol untuk memanggil leluhur dan Sanghyang Sri, Nyembur memiliki makna simbol sebagai penolak bala, pemotongan Indung Pare memiliki makna simbol sebagai permintaan izin kepada Sanghyang Sri untuk memotong padi, pembagian bakakak dan nasi uduk memiliki makna simbol sebagai tanda syukur. Hasil penelitian menunjukan masyarakat yang senantiasa
\end{abstract} memanjatkan rasa syukur atas rezeki yang dimiliki, berbagi sesama dan menghormati leluhurnya.

\section{A B S T R A C T}

Many people in Mekarsari Village carry out the Mipit Pare tradition but do not know the meaning of the symbols of the tradition. This research focuses on knowing the meaning of the symbols and the implementation process in the Mipit Pare tradition. This study uses a qualitative method with a descriptive approach. Data collection techniques were obtained from direct observation, interviews, and documentation. From the study results, it can be seen that the implementation of the Mipit Pare tradition has several stages. Each has a symbolic meaning, including Determining the day of implementation has a symbolic meaning that in determining something must be following the beliefs held so that undesirable things do not happen, offerings have symbolic meanings as a sign of gratitude to ancestors and Sanghyang Sri, reading kidung and burning incense have symbolic meanings to call ancestors and Sanghyang Sri, Nyembur has a symbolic meaning as a repellent to reinforcements, cutting Indung Pare has symbolic meaning as a request for permission to Sanghyang Sri to cut rice, the distribution of bakakak, and nasi uduk have symbolic meanings as a sign of gratitude. The study results show that people always express gratitude for the sustenance they have, share with others and respect their ancestors.

\footnotetext{
* Corresponding author.

E-mail addresses: muzizat.nurul17105@studentunsika.ac.id
} 


\section{Pendahuluan}

Provinsi Jawa Barat memiliki banyak kabupaten dengan masyarakat yang beragam dan berbeda suku, bangsa, agama serta ras. Badan Pusat Statistik (BPS) mencatat dengan luas sebesar 5,35\% dari wilayah Jawa Barat, Kabupaten Subang dihuni sebanyak 1,595 juta jiwa (September 2020) atau 3,30 persen penduduk Provinsi Jawa Barat (48,27 juta jiwa) (Elven Sukirno, 2021) Oleh karena itu, setiap daerah di Jawa Barat memiliki keanekaragaman budaya yang bervariasi. Masih banyak masyarakat di Jawa Barat yang mempertahankan dan menjunjung tinggi nilai-nilai kebudayaannya hingga saat ini. Salah satunya adalah masyarakat Desa Mekarsari Kecamatan Cikaum Kabupaten Subang. Desa Mekarsari termasuk bagian dari Provinsi Jawa Barat yang daerahnya dikelilingi oleh lahan pertanian, sehingga sebagian besar mata pencaharian masyarakatnya berasal dari sawah, ladang dan kebun. Jadi hampir semua yang berkaitan dengan pertanian bersifat sakral dan selalu diawali dengan ritual.

Ritual atau upacara tradisional adalah bagian integral dari kebudayaan masyarakat pendukungnya yang memiliki fungsi sebagai pengokoh norma-norma dan nilai-nilai yang berlaku dalam masyarakat. Hal ini disebabkan salah satu fungsi dari upacara tradisional yaitu menguatkan norma-norma serta nilai-nilai budaya yang berlaku. Norma-norma dan nilai-nilai itu secara simbolis ditampilkan melalui peragaan dalam bentuk upacara yang dilakukan dengan penuh khidmat oleh masyarakat pendukungnya, sehingga dengan upacara tersebut dapat membangkitkan rasa aman bagi setiap masyarakat di lingkungannya, serta dapat dijadikan pegangan bagi mereka dalam menentukan sikap dan tingkah lakunya sehari-hari. Penggunaan simbol dalam praktek upacara ternyata dilaksanakan dengan penuh kesadaran, pemahaman dan penghayatan yang tinggi, yang dianut secara tradisional dari generasi satu ke generasi berikutnya (Hafid \& Raodah, 2019).

Sebuah ritual merupakan tradisi yang diturunkan dari generasi ke generasi, kata "tradisi” berasal dari bahasa Latin, yaitu tradition yang berarti „diteruskan" atau "kebiasaan". Dalam pengertian yang paling sederhana adalah sesuatu yang dilakukan sejak lama dan menjadi bagian dari kehidupan suatu kelompok masyarakat, biasanya dari suatu negara, kebudayaan, waktu, atau agama yang sama. Hal yang paling mendasar dari tradisi adalah adanya informasi yang diteruskan dari generasi baik tertulis maupun lisan. Tanpa adanya hal itu, suatu tradisi akan punah (Anton \& Marwati, 2015). Masyarakat Desa Mekarsari memiliki banyak tradisi yang berhubungan dengan pertanian, setidaknya ada 5 tradisi yang masih dilakukan hingga sekarang diantaranya adalah Ruwat Bumi, Seren Taun, Babarit, Nyalin, dan yang menarik yaitu tradisi Mipit Pare karena, tradisi ini masih tetap rutin dilaksanakan ditengah terjangan budaya asing. Kebanyakan dari tradisi tersebut memiliki makna simbol yang hampir sama yaitu, untuk memanjatkan rasa syukur atas hasil bumi yang didapatkan.

Pada dasarnya makna yang terkandung dalam simbol-simbol ritual menjadi acuan sikap dan perilaku manusia yang tidak terlepas dari kehidupan masyarakat dengan orientasi kebudayaannya yang khas (Hafid \& Raodah, 2019) Jika, masyarakatnya tidak mengetahui makna dan tujuan dari tradisi tersebut, dikhawatirkan tradisi tersebut akan hilang dan terkikis seiring berjalannya waktu. Masin-masing simbol dalam pelaksanaan dan peralatannya mengandung penuh makna maka, harus dilakukan analisa agar makna dan simbol tersebut menjadi jelas maksud dan tujuannya sehingga, tradisi Mipit Pare tidak hanya dilakukan semata-mata untuk memanjatkan rasa syukur saja, tetapi juga dilakukan dalam rangka melestarikan adat istiadat yang didalamnya mengandung makna. Ciri khas simbol menurut Turner (dalam Endahwati, dkk. 2012: 157-170) yaitu: (a) multivokal, artinya simbol memiliki banyak arti menunjuk pada banyak hal, pribadi, dan fenomena, (b) polarisasi simbol , karena simbol memiliki banyak arti, sering ada arti simbol yang bertentangan, (c) unifikasi artinya memiliki arti terpisah (Raodah, 2009).

Dalam ritual Mipit Pare mengandung makna simbolik, dengan tujuan agar dapat diterapkan pada kehidupan sehari-hari dan berpedoman kepada kepercayaannya. Kekuatan simbol mampu menggiring orang yang mempercayai, mengakui, melestarikan atau mengubah persepsi hingga tingkah laku orang, dalam bersentuhan dengan realitas. Ritual secara simbolik dapat diartikan sebagai bentuk komunikasi manusia dengan transenden, seperti Tuhan, roh 
nenek moyang, Dewa, dan lainnya. Simbol adalah tanda, benda, dan kata yang memiliki makna. Setiap makna yang tercipta adalah hasil dari interaksi antara manusia. Begitupun dalam interaksi, manusia menggunakan interaksi verbal maupun non verbal. Komunikasi verbal (verbal communication) adalah bentuk komunikasi yang disampaikan komunikator kepada komunikan dengan cara tertulis (written) atau lisan (oral) sedangkan, Komunikasi nonverbal adalah komunikasi yang pesannya dikemas dalam bentuk tanpa kata-kata (Tri Indah Kusumawati, 2016).

Herbert Blumer mendefinisikan interaksionisme simbolik atau teori interaksi simbolik sebagai sebuah proses interaksi dalam rangka membentuk arti atau makna bagi setiap individu. George Herbert Mead menjelaskan bahwa manusia termotivasi untuk bertindak berdasarkan pemaknaan yang mereka berikan kepada orang lain, benda, dan kejadian. Pemaknaan ini diciptakan melalui bahasa yang digunakan oleh manusia ketika berkomunikasi dengan pihak lain yakni dalam konteks komunikasi antarpribadi atau komunikasi interpersonal dan komunikasi intrapersonal atauself-talkatau dalam ranah pemikiran pribadi mereka. Bahasa sebagai alat komunikasi memungkinkan manusia mengembangkan sense of self dan untuk berinteraksi dengan pihak lain dalam suatu masyarakat (Haris \& Amalia, 2018).

Banyak masyarakat Desa Mekarsari yang melakukan ritual Mipit Pare tetapi tidak memahami makna dan tujuan dari tradisi tersebut. Makna adalah arti atau maksud yang tersimpul dari suatu kata, jadi makna dengan bendanya sangat bertautan dan saling menyatu. Jika suatu kata tidak bisa dihubungkan dengan bendanya, peristiwa atau keadaan tertentu maka kita tidak bisa memperoleh makna dari kata itu (Muchlisin Riadi, 2013). Hal ini disebabkan karena kurangnya komunikasi diantara generasi ke generasi selain itu, penyebabnya juga berasal dari masyarakat terdahulu hanya menurunkan tradisi secara prakteknya saja, tidak menggunakan teori serta pemahaman mendalam mengenai makna simbol dari tradisi tersebut.

Tradisi Mipit Pare memiliki tujuan untuk memanjatkan rasa syukur kepada leluhur dan Dewi Padi karena telah memberikan padi yang subur dan berlimpah sehingga siap untuk dipanen dan terhindar dari segala macam gangguan dan penyakit. Menurut kepercayaan masyarakat Desa Mekarsari, apabila tidak melakukan tradisi Mipit Pare maka hidupnya akan lebih mudah terkena gangguan dan segala macam penyakit yang dapat merugikan diri dan keluarganya sehingga, masyarakat Desa Mekarsari rela mengorbankan tenaga dan materi demi terlaksananya tradisi Mipit Pare.

Sebuah makna dapat disampaikan melalui komunikasi. komunikasi adalah proses kegiatan pengoperan/penyampaian warta/berita/informasi yang mengandung arti dari satu pihak (seseorang atau tempat) kepada pihak (seseorang atau tempat) lain dalam usaha mendapatkan saling pengertian (Oktavia, 2016). Begitupun dengan sebuah makna simbol dalam tradisi Mipit Pare, makna simbol yang terdapat dalam tradisi Mipit Pare dapat diwariskan dari generasi ke generasi yaitu dengan cara komunikasi. Agar tradisi Mipit Pare tetap bertahan diera globalisasi, maka masyarakat perlu berkomunikasi dengan orang-orang terdahulu yang mengetahui makna simbolik dari tradisi tersebut. Hal ini dapat dibuktikan dari orang-orang yang sering berkomunikasi dengan Tokoh Adat atau masyarakat terdahulu, mereka mengetahui lebih jelas mengenai makna simbol dan tujuan dari tradisi Mipit Pare.

Pada setiap proses pelaksanaannya tradisi Mipit Pare mengandung makna simbol baik berupa kata ataupun benda, pada penentuan hari pelaksanaan mengandung simbol bahwa dalam mengambil sebuah keputusan tidak boleh sembarangan dan harus sesuai dengan kepercayaan, pembacaan kidung dan membakar kemenyan memiliki makna simbol untuk memanggil roh leluhur dan Dewi Padi, sesajen memiliki makna simbol sebagai tanda terimakasih yang dipersembahkan kepada roh leluhur dan Dewi Padi, pelaksanaan Nyembur memiliki makna simbol sebagai penolak bala, pemotongan Indung Pare memiliki makna simbol permintaan izin untuk memotong padi yang akan dipanen, dan pembagian bakakak serta nasi uduk memiliki makna simbol sebagai tanda syukuran. Adapun tujuan dari penelitian ini adalah untuk mengetahui proeses pelaksanaan dan makna simbol yang terdapat dalam tradisi Mipit Pare di Desa Mekarsari. 


\section{Metode}

Metode penelitian ini menggunakan metode kualitatif, maksud dari penelitian ini adalah mendeskripsikan data yang diperoleh dari orang yang terlibat langsung dalam tradisi Mipit Pare. Penelitian kualitatif ini didasarkan pada pendekatan karakteristik penelitian antara lain: pertama pada penelitian kualitatif, pengumpulan datanya dilakukan dalam latar yang wajar atau alamiah (natural setting), bukan dalam kondisi yang terkendali atau laboratories. Kedua, metode yang dilakukan dalam penelitian ini didasarkan pada fenomena sosial, penelitian kualitatif yaitu penelitian yang menghasilkan data diskriptif berupa kata-kata tertulis atau lisan dari orangorang dan pelaku yang dapat diamati. Ketiga, pendekatan ini diarahkan pada individu yang utuh (Raodah, 2009)

Lokasi penelitian di Desa Mekarsari Kecamatan Cikaum Kabupaten Subang, Provinsi Jawa Barat. Pemilihan lokasi ini dipilih berdasarkan atas pertimbangan bahwa tradisi Mipit Pare sudah ada sejak dahulu dan hanya dilakukan oleh masyarakat Desa Mekarsari, Walaupun tradisi Mipit Pare ada di wilayah lain di Jawa Barat, tetapi tradisi ini memiliki makna dan proses pelaksanaan yang sangat berbeda. Data yang diperoleh dari penelitian ini berasal dari dua sumber, yaitu data primer dan data sekunder. Data primer adalah data yang diperoleh melalui observasi langsung dan wawancara. Data sekunder diperoleh dari jurnal, buku, dan penelitian terdahulu yang berbentuk laporan, dan sebagainya yang berhubungan dengan penelitian ini (Tanujaya, 2017). Untuk memperoleh data yang relevan peneliti melakukan wawancara kepada Tokoh Adat, masyarakat terdahulu, dan masyarakat yang hingga kini masih melaksanakan ritual Mipit Pare. Teknik analisis data yang digunakan dalam penelitian ini adalah analisis deskriptif kualitatif. Adapun analisis data yang digunakan dalam peneilitian ini antara lain : reduksi data, penyajian data, dan penarikan kesimpulan (Nurdin, 2019).

\section{Hasil dan Pembahasan Profil Desa Mekarsari}

Desa Mekarsari merupakan salah satu Desa yang terletak dibagian utara Kabupaten Subang. lahan yang ada di Desa Mekarsari sebagian besar adalah lahan pertanian, hampir seluruh masyarakat Desa Mekarsari bergantung kepada alam. Masyarakat Desa Mekarsari percaya bahwa manusia dan alam mampu bekerja sama untuk menciptakan sesuatu yang bermanfaat dan saling menguntungkan. Fokus pertanian di Desa Mekarsari adalah pesawahan, jadi sebagian besar masyarakat Desa Mekarsari berprofesi sebagai petani.Walaupun begitu, tidak seluruh masyarakat Desa Mekarsari adalah petani. Sebagian bekerja sebagai pegawai swasta dan wirausaha. Desa Mekarsari merupakan desa yang masih asri dan memiliki banyak pepohonan sehingga menyebabkan Desa terasa sejuk dan nyaman. Desa ini juga dikelilingi oleh persawahan yang luas. Masyarakat Desa mekarsari sudah mulai mengikuti zaman ke era digital, terbukti dari banyaknya pengguna media sosial.

Masyarakat Desa Mekarsari secara keseluruhan beragama islam, merupakan penganut agama islam yang taat dan melaksanakan ajaran sesuai dengan syariat islam. Ketaatan masyarakat dapat dilihat dari banyaknya bangunan masjid dan selalu terlihat ramai oleh jamaah ketika beribadah shalat jumat maupun shalat lima waktu. Selain itu, masjid juga dijadikan sebagai tempat untuk menuntut ilmu agama sehingga selalu dipenuhi oleh santri. Namun demikian, dalam kehidupan masyarakat Desa Mekarsari masih ditemukan beberapa kepercayaan kepada Nenek Moyang. Salah satunya yaitu berbentuk ritual yang diwariskan oleh para Leluhur. Ritual yang masih dilakukan hingga sekarang di Desa Mekarsari adalah tradisi Mipit Pare, Tradisi ini merupakan bentuk penghormatan kepada roh leluhur dan Dewi Padi karena diberikan padi yang berlimpah. Alasan sebagian masyarakat Desa Mekarsari masih melakukan tradisi tersebut agar terhindar dari segala gangguan dan penyakit.

Desa Mekarsari terbagi menjadi tujuh Dusun, diantaranya adalah Dusun Gombong, Karang Tanjung, Karang Toman, Ciawitali 1, Ciawitali 2, Tegalwaru, dan Duwet. Pada Desember 2020 Desa Mekarsari memiliki jumlah penduduk mendekati 11.071 jiwa dari jumlah kepala keluarga (KK) sebanyak 3.856. dilihat dari sudut geografis, Desa Mekarsari mempunyai luas wilayah 770.233 Ha. Dari data tersebut, dapat terlihat kehidupan masyarakat Desa Mekarsari 
jauh dari kata sejahtera, terbukti dari bentuk rumah yang belum permanen dan sebagian hanya terbuat dari bilik. Akses jalan di Desa Mekarsari sebagian besar masih tanah dan belum terkena aspal, hal ini menyebabkan sulit untuk dilewati kendaraan.

\section{Asal mula Tradisi Mipit Pare}

Sebuah tradisi yang diwariskan dari Nenek Moyang tidak pernah terlepas dari sejarah, Tradisi Mipit Pare dimulai ketika Sanghyang Sri yang berasal dari langit ketujuh turun ke bumi. Ia memiliki 4 saudara, yang bernama Jaka Sela, Jaka Pamor, Jaka Wesi, Jaka Sengara. Orang tua mereka berpisah sehingga menyebabkan keempat saudaranya tersebut tinggal bersama ayahnya sedangkan, Sanghyang Sri tinggal bersama ibunya. Salah satu saudaranya yang bernama Jaka Sengara menyukai Sanghyang Sri dan berinat untuk menikahinya, karena beliau adalah saudara kandung Sanghyang Sri maka, ibunya melarang Jaka Sengara untuk menikahi Sanghyang Sri. Tetapi keduanya saling mencintai dan akan segera melangsungkan pernikahan. Namun, ibu Sanghyang Sri masih saja tidak menyetujui jika keduanya menikah. Maka dari itu, ibunya meniupkan bambu yang memiliki bulu-bulu dikepala Jaka Sengara, sehingga menyebabkan gatal-gatal diseluruh tubuhnya. Setelah itu, Jaka Sengara berubah menjadi lelaki buruk rupa dan jika siapapun yang melihatnya akan merasa jijik. Begitupun dengan Sanghyang Sri, setelah mengetahui keadaan Jaka Sengara berubah maka ia tidak mau lagi menikah dengannya. Jaka Sengara berusaha keras untuk dapat menikahi Sanghyang Sri bagaimanapun caranya. Salah satu usahanya yaitu, Jaka Sengara meminta kepada ayahnya untuk merubah bentuk fisiknya agar dapat menikahi Sanghyang Sri. Ayahnya diketahui memiliki ilmu yang mampu merubah bentuk fisiknya. Akan tetapi, ayahnya juga tidak menyetujui jika Jaka Sengara dan Sanghyang Sri menikah karena, mereka adalah saudara kandung. Lalu, ayahnya mengeluarkan sebuah keris untuk memotong leher Jaka Sengara. Karena ayahnya takut jika anaknya akan tetap menikahi Sanghyang Sri yang merupakan putri pertamanya, maka dipotonglah leher Jaka Sengara menggunakan keris tersebut, seketika Jaka Sengara langsung meninggal. Tetapi ayahnya merasa menyesal telah membunuh anaknya sendiri. Setelah itu, Jaka Sengara diminta oleh guru ayahnya untuk dikuburkan ditanah Makkah, tidak boleh ditanah Jawa. Sebab, jika Jaka Sengara dikuburkan ditanah Jawa dan diketahui oleh seluruh saudaranya maka, dikhawatirkan akan mengakibatkan pertumpahan darah antara dirinya dengan anakanaknya. Kemudian ketika peti mati Jaka Sengara dibawa menuju tempat pemakaman, ditengah perjalanan pembawa peti merasa lelah dan beristirahat sejenak. Pembawa peti lupa bahwa peti Jaka Sengara tidak boleh disimpan dibawah karena akan terjadi sesuatu, tidak lama kemudian peti yang berisi mayat Jaka Sengara meledak. Lalu, mayat Jaka Sengara berubah menjadi berbagai tumbuh-tumbuhan. Tangannya menjadi pohon singkong, kakinya menjadi pohon umbi, dan kepalanya menjadi pohon sintung gebang.

Akhirnya ayah dari Jaka Sengara merahasiakan kejadian tersebut dari ibu dan seluruh saudaranya, sehingga tidak ada yang mengetahui keberadaan Jaka Sengara. Setelah beberapa lama kemudian, Sanghyang Sri bertemu dengan lelaki yang ia cintai, tetapi lelaki tersebut hanya bermain-main dengan Sanghyang Sri sehingga pada suatu hari ia diberi buah yang bernama koldi, buah tersebut memiliki racun sehingga menyebabkan Sanghyang Sri meninggal dunia. Ketika meninggal dan dikuburkan setelah beberapa menit, dari bawah kuburannya tumbuh berbagai macam tumbuhan. Bagian kakinya tumbuh pohon tebu, sedangkan bagian kepalanya tumbuh pohon padi.

Lalu ketika ayahnya melihat hal tersebut, ia berniat untuk memotong pohon padi itu. Tetapi ketika akan dipotong semua, yang bisa dipotong hanyalah 8 tangkai sedangkan yang lainnya sangat sulit untuk dipotong. Pada malam harinya, ketika ayahnya tertidur ia bermimpi didatangi oleh putrinya tersebut, dalam mimpinya Sanghyang Sri memberi pesan bahwa jika ada siapapun yang ingin memotong padi maka harus membacakan kidung dan memberikan sebuah sesajen untuk dirinya, hal tersebut memiliki makna agar manusia senantiasa berterima kasih kepadanya yang telah memberikan padi bagi semua umat manusia. Dari sejarah inilah masyarakat Desa Mekarsari selalu melaksanakan tradisi Mipit Pare. 
Menurut bahasa Mipit artinya adalah memetik sedangkan Pare artinya adalah padi. Jadi, Mipit Pare adalah aktivitas memetik Indung Pare sedangkan, menurut istilah Mipit Pare memiliki makna sebagai simbol rasa syukur masyarakat kepada Dewi Padi (Sanghyang Sri) atas hasil padi yang berlimpah. Memetik disini memiliki makna multi tafsir, yaitu diartikan sebagai cara meminta izin, penghormatan, syukuran, serta ajang silaturahmi antar kerabat. Dalam pelaksanaannya tradisi Mipit Pare dilaksanakan oleh orang-orang yang memiliki sawah, makin banyak sawahnya maka makin banyak pula tradisi Mipit Pare dilakukan. Tradisi ini dilakukan dengan tujuan untuk memanjatkan rasa syukur kepada leluhur dan Dewi Padi sedangkan fungsi dari dilaksanakannya tradisi Mipit Pare agar menjauhkan diri dari segala macam gangguan dan penyakit juga dapat mendekatkan diri kepada roh nenek moyang agar hidup menjadi lebih tentram dan damai. Demi tercapainya tujuan dan fungsi dari tradisi Mipit Pare, masyarakat Desa Mekarsari rela mengorbankan materi dan tenaganya.

\section{Proses pelaksanaan Tradisi Mipit Pare}

Dalam kegiatannya, Mipit Pare dilaksanakan di sawah dan dihadiri oleh sebagian masyarakat yang ingin mengikuti ritual tersebut. Ritual Mipit Pare biasanya dipimpin oleh pemilik sawah, untuk menuju sawahnya masyarakat diwajibkan untuk berjalan kaki. Pemilik sawah menggunakan baju koko dan peci sedangkan masyarakat boleh menggunakan pakaian apapun. Tidak ada patokan bagi siapapun yang ingin mengikuti ritual ini, baik perempuan maupun lelaki semuanya diperbolehkan untuk hadir. Tradisi Mipit Pare biasanya dilaksanakan tiga hari sebelum padi akan dipanen. Tradisi Mipit Pare memiliki tiga tahapan, yaitu tahap persiapan, pelaksanaan dan penutup.

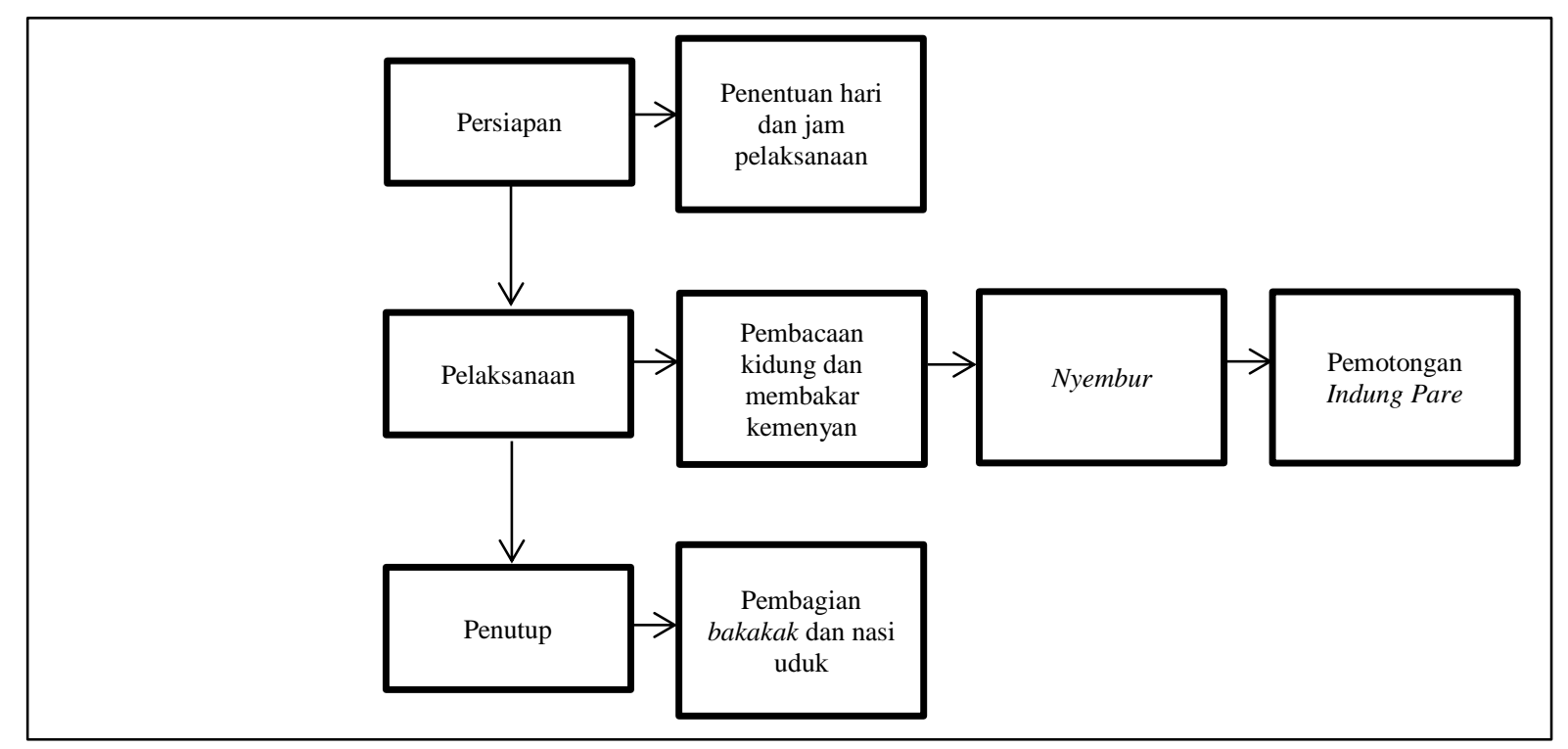

Gambar 1. Proses pelaksanaan tradisi Mipit Pare

Tahap pertama adalah persiapan, pada tahap ini yang pertama kali dilakukan adalah menentukan hari dan jam pelaksanaan, penentuan hari ini bisa dilaksanakan pada hari apa saja kecuali hari senin, karena pada hari senin Sanghyang Sri sedang membuang kotorannya, jadi tidak etis dan tidak sopan jika melaksanakan ritual pada hari senin. Lalu, menentukan jam pelaksanaan, ritual Mipit Pare sebaiknya dilaksanakan pada jam 11.00 WIB, 16.00 WIB, dan 17.00 WIB. Masyarakat Desa Mekarsari percaya bahwa pada jam-jam tersebut Sanghyang Sri sedang turun ke bumi sehingga dapat menyaksikan tradisi Mipit Pare. Selanjutnya mempersiapkan sesajen untuk dipersembahkan kepada leluhur dan Dewi Padi. Biasanya, Sesajen dibawa pemilik sawah menggunakan kain berwarna putih lalu diikat agar tidak berceceran. Setelah sampai di sawah sesajen disimpan di Sasanggar, benda ini terbuat dari kayu, memiliki ukuran yang cukup panjang dan diatasnya terdapat bagian bulat sebagai tempat 
menyimpan sesajen. Sasanggar ini biasanya dibuat oleh pemilik sawah ketika padi sudah mulai siap untuk dipanen dan disimpan dibagian pojok sawah.

Tahap yang kedua yaitu pelaksanaan, pada tahap pelaksanaan ritual dimulai dengan pembacaan kidung dan doa khusus sambil membakar kemenyan yang dipimpin oleh pemilik sawah yang dipersembahkan kepada Roh Leluhur dan Dewi Padi. Bagi masyarakat yang mengikuti ritual tersebut tidak diperbolehkan untuk mengobrol satu sama lain agar acara berjalan dengan khidmat selain itu, masyarakat juga wajib menundukan kepala ketika kidung dibacakan. Pada pembacaan kidung sambil membakar kemenyan ini memiliki makna untuk memanggil Leluhur dan Dewi Padi agar dapat menyaksikan ritual Mipit Pare. Lalu, minyak duyung dibukakan sebagai persembahan untuk Dewi Padi agar meminumnya. Selain itu, Dewi Padi juga akan memakan bunga tujuh rupa yang telah disediakan oleh pemilik sawah. Proses selanjutnya adalah acara Nyembur, yaitu pemilik pare meminum air putih yang sudah dijampe dan selanjutnya disemburkan ke bagian depan, belakang, kanan dan kiri sawah. Hal ini bertujuan sebagai penolak bala.

Proses selanjutnya yaitu acara inti dari tradisi Mipit Pare, yaitu memotong Indung Pare. Pada pelaksanaan tradisi Mipit Pare wajib menggunakan alat-alat yang tradisional, jika pada era sekarang memotong padi menggunakan arit ataupun alat canggih lainnya, berbeda dengan alat yang digunakan dalam tradisi Mipit Pare. Alat yang digunakan untuk memotong padi dinamakan ani-ani. Alat ini terbuat dari bambu, terdapat sisi yang tajam dan memiliki bentuk yang unik. Indung Pare yang dipilih harus merupakan padi yang paling bagus dan hanya 8 tangkai yang dipotong. Setelah dipotong, Indung Pare diikat bersama bunga menggunakan kain putih lalu, diberi wewangian. Pemotongan Indung Pare ini memiliki makna simbol meminta izin kepada Dewi Padi untuk memanen sawahnya. Indung Pare yang telah dipotong nantinya akan digantung didepan pintu rumah agar padi yang belum dipanen terhindar dari segala macam gangguan dan kerusakan. Menurut masyarakat Desa Mekarsari mahluk halus tidak berani mengganggu apabila Indung Pare digantungkan didepan pintu. Setelah Indung Pare dipotong dan disimpan didepan pintu rumah, nantinya Indung Pare tersebut disatukan dengan padi yang banyak. Sebelum disatukan, padi yang telah dipanen harus dijemur dibawah sinar matahari sampai kering, lalu setelah proses penjemuran selanjutnya padi disimpan di leuwi atau tempat penyimpanan padi.

Tahapan yang terakhir yaitu penutup, pada tahap penutupan dari tradisi Mipit Pare ini yaitu melakukan pembagian Bakakak dan nasi uduk kepada masyarakat yang mengikuti tradisi tersebut. Pembagian Bakakak dan nasi uduk ini memiliki arti sebagai syukuran atas padi yang sudah siap untuk dipanen. Setiap orang biasanya mendapatkan satu bungkus. Setelah semuanya dibagi rata, masyarakat Desa Mekarsari biasanya berkumpul di Dangau (rumah kecil ditengah sawah) sawah untuk memakan bakakak dan nasi uduk bersama-sama. Sesajen yang dibawa oleh pemilik sawah disimpan hingga pada waktu panen tiba.

Tradisi Mipit Pare memiliki banyak komunikasi verbal dan nonverbal, komunikasi nonverbal salah satunya adalah simbol dari berbagai sesajen sedangkan, komunikasi verbalnya yaitu ketika bersilaturahmi dengan dan orang-orang yang mengikuti tradisi tersebut. Komunikasi nonverbal yang ada dalam tradisi Mipit Pare memiliki makna yang mendalam bagi masyarakat Desa Mekarsari. Makna yang ada dalam tradisi Mipit Pare ini adalah hasil kesepakatan bersama antara masyarakat Desa Mekarsari dengan tokoh adat dan pemerintah setempat.

Makna yang terkandung dalam sesajen tersebut memiliki arti dan persembahan yang berbeda jika kopi, teh, rokok, umbi-umbian, bubur beras merah dan putih, pisang batu, bakakak dan nasi uduk dipersembahkan kepada roh leluhur sebagai bentuk terimakasih karena telah menjaga sawah dari gangguan dan kerusakan sedangkan, bunga tujuh rupa, minyak duyung, kelapa muda, bedak, sisir dan lipstik dipersembahkan untuk Sang Hyang Sri. Minyak duyung dipersembahkan untuk diminum, bunga tujuh rupa untuk dimakan, dan kelapa muda sebagai tempat cuci tangannya. Selain itu, bedak, sisir dan lipstik dipergunakan Sang Hyang Sri untuk mempercantik dirinya. 


\section{Makna simbol dalam tradisi Mipit Pare}

Hampir seluruh kebudayaan memiliki makna tersendiri bagi setiap pemegang kepercayaannya, makna tersebut terkandung didalam simbol-simbol baik berbentuk kata, benda, maupun tanda. Pengetahuan, kepercayaan, norma dan nilai-nilai tidak dapat eksis tanpa adanyasimbol-simbol. Simbol memungkinkan manusia untuk menciptakan, mengkomunikasikan dan mengambil bagian serta mengalihkan komponen-komponen kebudayaan ke generasi berikutnya (Raodah, 2009). Dalam setiap rangkaian prosesi ritual Mipit Pare memiliki makna dan pesan bagi setiap generasi yang diwariskan dari para leluhurnya. Adapun beberapa makna simbol dalam tradisi Mipit Pare, diantaranya sebagai berikut.

\section{Makna simbol dalam interaksi masyarakat}

Dalam kehidupan bermasyarakat manusia tidak akan pernah terlepas dari interaksi sosial, Interaksi sosial adalah kunci dari semua kehidupan sosial, tanpa adanya interaksi sosial tidak akan mungkin ada kehidupan secara bersama-sama. Syarat utama dari adanya atau hadirnya aktivitas-aktivitas sosial adalah adanya interaksi sosial (Xiao, 2018). Untuk menginterpretasikan sebuah makna manusia mengkomunikasikan arti-arti kepada orang lain melalui simbol-simbol, lalu orang lain memberikan makna kepada simbol tersebut sesuai dengan persepsi mereka. Dengan kata lain, dalam interaksi sosial, orang-orang terlibat dalam proses saling mempengaruhi. Dalam proses tradisi Mipit Pare masyarakat mengikuti acara tersebut dengan khidmat dan penuh keyakinan. Hal ini memiliki makna simbol bahwa masyarakat Desa Mekarsari memberikan dukungan dan kecintaan mereka terhadap roh Nenek Moyang dan Dewi Padi selain itu, berkumpulnya masyarakat dijadikan sebagai ajang silaturahmi yang memiliki simbol eratnya tali persaudaraan dan kebersamaan. Terdapat simbol keikhlasan dari para orang-orang yang mengikuti acara tersebut karena rela berjalan kaki menyusuri galengan sawah yang sempit dan kotor. Ketika proses pembagian bakakak memiliki makna simbol yaitu keikhlasan pemilik sawah untuk memberikan sebagian rezekinya kepada sesama manusia.

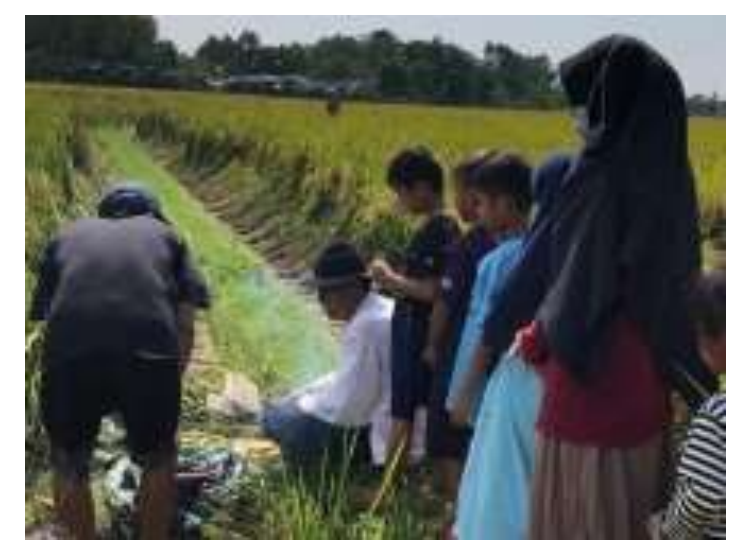

Gambar 2. Masyarakat yang berjalan di galengan sawah

Tiga tema konsep pemikiran George Herbert Mead yang mendasari interaksi simbolik antara lain: (1) pentingnya makna bagi perilaku manusia; (2) pentingnya konsep mengenai diri; (3) hubungan antara individu dengan masyarakat. Begitupun dalam tradisi Mipit Pare, masyarakat Desa Mekarsari menciptakan sebuah makna atas hasil interaksi dengan dirinya sendiri dan orang lain menggunakan simbol, gesture, dan tindakan. Pada saat pembacaan kidung, masyarakat yang mengikuti ritual tersebut menundukan kepala tanda menghormati kepada leluhur dan Dewi Padi. Tentu hal ini mencerminkan masyarakat Desa Mekarsari yang tunduk patuh terhadap leluhurnya. Selain itu, ketika orang-orang berkumpul dan saling bersilaturahmi dalam ritual tersebut menandakan masyarakat yang memiliki solidaritas dan menghargai leluhurnya. Sanghyang Sri dikenal sebagai seseorang yang baik hati karena telah memberikan penghidupan bagi masyarakat Desa Mekarsari berupa padi yang 
berlimpah, oleh karena itu, masyarakat sangat menghormatinya. Simbol dari penghormatan masyarakat dapat terlihat ketika mereka rela mengorbankan materi dan tenaga demi terlaksananya ritual Mipit Pare.

\section{Makna simbol penentuan hari dan jam pelaksanaan}

Dalam pelaksanaan tradisi Mipit Pare tidak boleh asal dalam pemilihan hari dan jamnya, semuanya sudah diatur berdasarkan kepercayaan masyarakat terdahulu. Ritual Mipit Pare tidak boleh dilaksanakan pada hari senin, karena pada hari tersebut Sanghyang Sri sedang membuang kotorannya jadi tidak sopan dan tidak etis jika melakukan ritual. Jam pelaksanaan ritual Mipit Pare diantara pukul 11.00 WIB, 16.00 WIB, 17.00 WIB, pada jam tersebutlah roh leluhur dan Sanghyang Sri sedang turun ke bumi dan dapat menyaksikan ritual tersebut. Penentuan hari dan jam pelaksanaan memiliki makna simbol bahwa dalam melaksanakan sesuatu tidak boleh sembarangan, harus sesuai dengan ketentuan berdasarkan kepercayaan.

\section{Makna simbol sesajen}

Pada ritual Mipit Pare, sesajen adalah segala sesuatu yang berisi makanan, minuman dan peralatan upacara lainnya. Kemenyan yang dibakar memiliki makna simbol sebagai cara untuk memanggil roh para leluhur agar berkumpul dan menyaksikan ritual Mipit Pare. Kopi, teh, rokok, umbi-umbian, bubur beras merah dan putih, pisang batu, bakakak dan nasi uduk memiliki makna simbol yang sama yaitu, sebagai bentuk terima kasih kepada roh leluhur dan Sanghyang Sri karena telah memberikan hasil padi yang berlimpah sehingga siap untuk dipanen. Masyarakat merasa bahwa mereka adalah manusia yang beruntung karena telah diberikan padi yang berlimpah maka dari itu, sebagai timbal baliknya dan ucapan terimakasihnya masyarakat memberikan sesajen agar dapat dinikmati oleh leluhur dan Sanghyang Sri. Sesajen tersebut nantinya akan dimakan perisanya oleh para leluhur, sehingga ketika dimakan oleh manusia tidak memiliki rasa apapun.

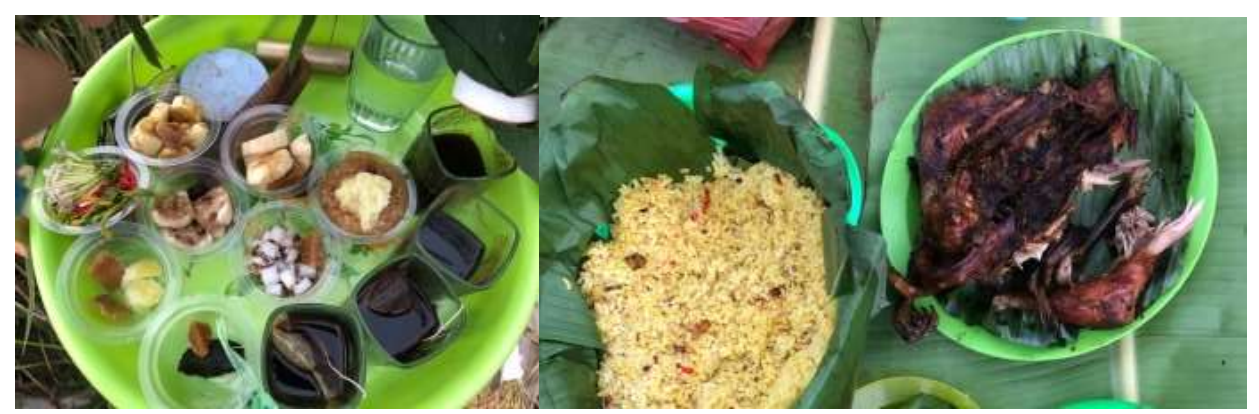

Gambar 3. Sesajen, bakakak dan nasi uduk

Bakakak dan nasi uduk adalah makanan yang istimewa pada zaman kerajaan, konon pada zaman dulu yang bisa memakan bakakak dan nasi uduk hanyalah keluarga kerajaan saja. Oleh karena itu, makanan ini dipersembahkan secara khusus untuk roh Leluhur sedangkan, sesajen untuk Sanghyang Sri yaitu bunga tujuh rupa sebagai makanannya, minyak duyung sebagai minumannya, kelapa muda digunakan sebagai air untuk mencuci tangannya, bedak, sisir dan lipstik digunakan untuk mempercantik dirinya. Menurut masyarakat desa mekarsari Sanghyang Sri tidak memakan makanan seperti layaknya manusia, ia memakan bunga dan meminum minyak duyung. Bunga tujuh rupa dan minyak duyung adalah simbol bahwa Masyarakat Desa Mekarsari mencintai dan menghormati Sanghyang Sri sebagai Dewi Padi, air kelapa muda memiliki makna simbol sebagai air suci yang nyata, sehingga dapat mensucikan. Bedak, lipstik dan sisir memiliki makna simbol sebagai alat yang dipersembahkan kepada Sanghyang Sri untuk mempercantik dirinya. Jadi, sesajen dalam tradisi Mipit Pare memiliki makna simbol untuk memberikan ucapan terimakasih, penghormatan dan memanjatkan rasa syukur kepada roh Leluhur dan Sanghyang Sri. 


\section{Makna simbol membaca kidung sambil membakar kemenyan}

Sebuah ritual tidak akan terlepas dari kemenyan yang sudah dibacakan jampe, lalu dibakar agar wanginya tercium. Kemenyan biasanya memiliki aroma wangi yang khas. Aroma wangi dari kemenyan sangat disukai oleh roh Leluhur sengingga dapat dijadikan sebagai alat untuk memanggilnya. Kemenyan memiliki bentuk yang keras seperti kerikil tetapi rapuh dan bisa dibakar. Dalam tradisi Mipit Pare pembacaan kidung sambil membakar kemenyan adalah suatu yang wajib dilakukan, karena ketika membaca kidung sambil membakar kemenyan dipercaya dapat memanggil roh leluhur dan dewi padi untuk menyaksikan ritual tersebut.

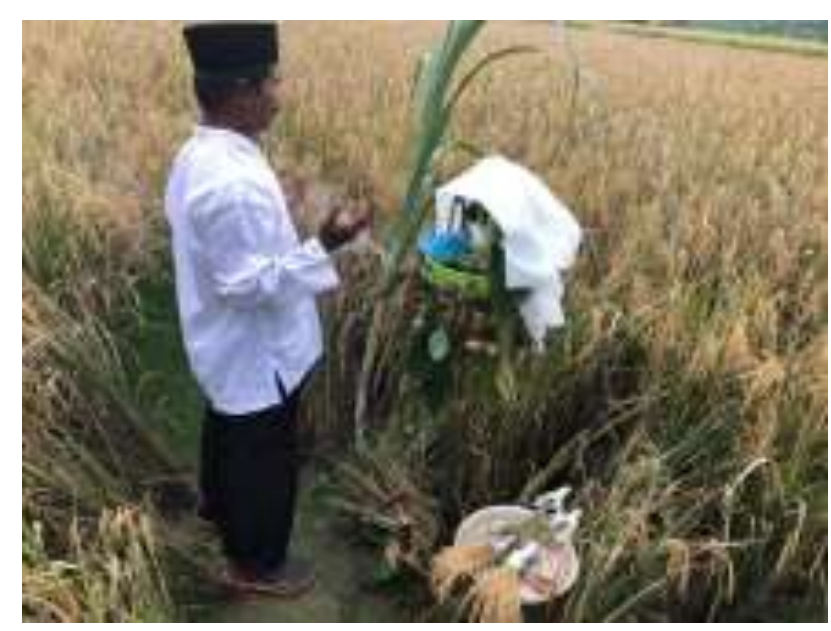

Gambar 4. Proses pembacaan kidung dan membakar kemenyan

Ketika pembacaan kidung, masyarakat harus menundukan kepala, hal ini memiliki makna sebagai tanda hormat mereka terhadap roh leluhur dan Dewi Padi. Pada proses ini memiliki makna simbol sebagai cara untuk memanggil roh Leluhur dan Dewi Padi.

\section{Makna simbol Nyembur}

Tradisi Mipit Pare memiliki beberapa proses pelaksanaan, salah satunya adalah proses yang disebut dengan Nyembur, pada proses ini pemilik sawah akan meminum air putih yang telah dibacakan jampe lalu air tersebut disemburkan ke arah depan, belakang, kanan, dan kiri sawah. Hal ini memiliki makna simbol sebagai penolak bala, agar terhindar dari segala macam gangguan dan kerusakan.

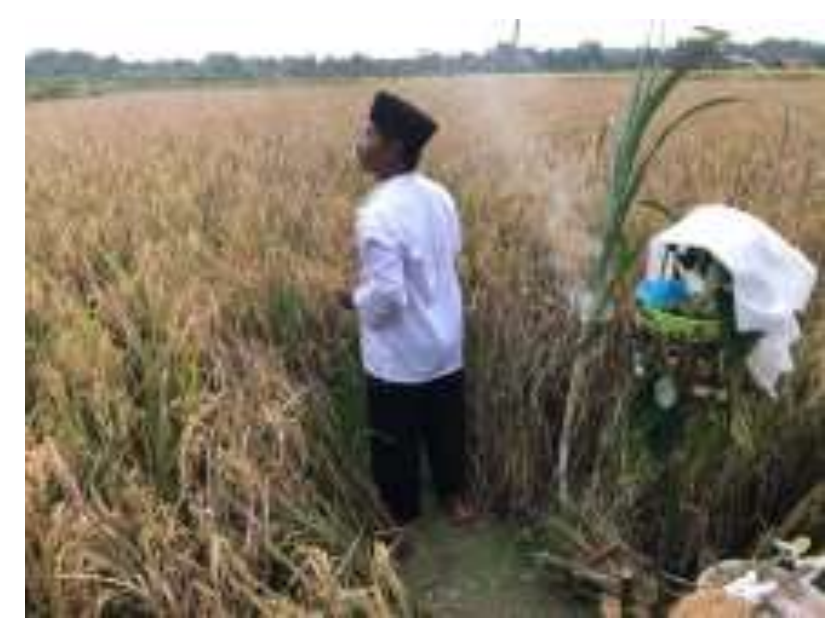

Gambar 5. Proses Nyembur 


\section{Makna simbol pemotongan Indung Pare}

Pemotongan Indung Pare merupakan hal terpenting dari ritual Mipit Pare, tanpa memotong Indung Pare ritual tidak dapat dikatakan sah. Padi yang dipilih untuk dipotong harus padi yang bagus, jumlah padi yang dipotong hanyalah dua ikat saja, masing-masing ikatan berjumlah empat tangkai, jadi jumlah Indung Pare yang dipotong adalah delapan tangkai. Memotong Indung Pare tidak menggunakan sembarang alat, pemilik sawah memiliki alat khusus untuk memotong Indung Pare yaitu ani-ani. Ani ani terbuat dari bambu, memiliki ukuran kecil dan terdapat sisi yang tajam.

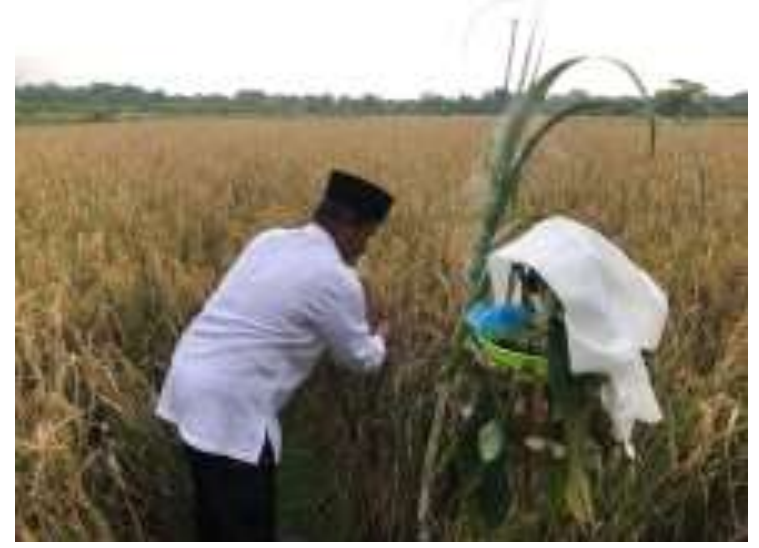

Gambar 6. Proses pemotongan Indung Pare

Indung Pare yang telah di potong lalu digantung didepan pintu rumah. Menurut kepercayaan, hal ini memiliki makna simbol yang artinya dapat mengusir segala roh jahat agar padi yang belum dipanen tetap utuh dan tidak ada gangguan apapun sampai waktunya tiba untuk dipanen. Setelah semua padi dipanen, Indung Pare yang digantung tersebut akan diambil dan disatukan bersama padi yang lainnya, lalu, padi yang sudah selesai dipanen disimpan di leuwi. Pemotongan Indung Pare juga memiliki makna simbol yang mendalam, dilakukannya pemotongan Indung Pare adalah simbol bahwa pemilik sawah meminta izin kepada Sanghyang Sri untuk memanen sawahnya.

\section{Makna simbol pembagian bakakak dan nasi uduk}

Tradisi Mipit Pare memiliki makna sebagai simbol rasa syukur, maka dari itu masyarakat Desa Mekarsari percaya bahwa tradisi Mipit Pare juga dijadikan sebagai simbol syukuran, masyarakat di Desa Mekarsari percaya bahwa sebuah acara syukuran harus diakhiri dengan memberikan sesuatu yang bermanfaat bagi masyarakat lainnya baik berupa barang atau makanan. Karena tradisi Mipit Pare juga adalah acara syukuran, oleh sebab itu dalam ritual ini memiliki kegiatan pembagian bakakak dan nasi uduk kepada masyarakat.

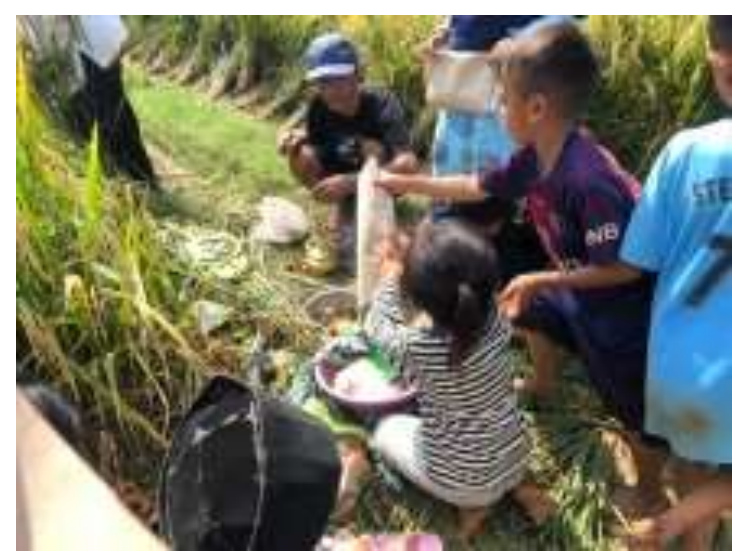

Gambar 7. Proses pembagian bakakak dan nasi uduk 
Pembagian bakakak dan nasi uduk memiliki makna simbol yaitu, karena telah diberikan padi yang banyak dan melimpah oleh Dewi Padi maka atas rasa terima kasihnya pemilik sawah membagikan sebagian rezeki yang didapatkan agar menjadi berkah. Masih banyak masyarakat Desa Mekarsari yang melaksanakan tradisi Mipit Pare hanya karena perintah dari Leluhurnya, biasanya hal ini banyak terjadi pada masyarakat yang sudah mulai bergeser ke budaya modern. Meskipun tidak mengetahui makna dan tujuannya tetapi mereka tetap melaksanakan tradisi tersebut.

Oleh sebab itu, agar tradisi dari warisan leluhur dapat diketahui oleh setiap generasi sebagai bentuk pedoman kepercayaan kepada Leluhurnya maka komunikasi sangat diperlukan untuk mengetahui makna simbol dan tujuan dari tradisi tersebut. Komunikasi adalah bentuk interaksi manusia yang saling mempengaruhi satu sama lain, sengaja atau tidak sengaja dan tidak terbatas pada bentuk komunikasi verbal, tetapi juga dalam hal ekspresi muka, lukisan, seni, dan teknologi. (Corytawaty \& Lobodally, 2017) Masyarakat terdahulu harus mengkomunikasikan makna simbol ke setiap generasi ataupun sebaliknya, generasi yang baru harus berusaha memenuhi kebutuhan mengenai informasi terhadap tradisi yang merupakan ciri khas daerahnya, yaitu dengan cara menggali informasi kepada Tokoh Adat ataupun masyarakat terdahulu yang mengetahui banyak tentang tradisi Mipit Pare.

Sebagai masyarakat yang memiliki kepercayaan kepada roh Nenek Moyang, harus mempunyai sikap kepedulian dan kecintaan terhadap tradisi demi mempertahankan tradisi tersebut. Salah satunya adalah dengan cara melestarikan tradisi tersebut kepada anak cucu agar nilai-nilai kebudayaan tetap utuh. Cara melestarikan tradisi seharusnya tidak hanya berbentuk praktek saja, apabila sebuah tradisi hanya diwariskan secara praktek maka tidak akan dilakukan dengan khidmat karena, yang melakukan tradisi tersebut tidak mengetahui makna dan tujuan dari tradisi tersebut. Oleh sebab itu, penting bagi masyarakat terdahulu untuk menginformasikan sebuah makna simbol kepada generasi selanjutnya.

Selain itu, perlu adanya dukungan dari pemerintah setempat untuk memberikan ruang dan peluang kepada masyarakat yang memiliki kepercayaan terhadap roh Nenek Moyang untuk tetap melestarikan kebudayaan tersebut karena sebuah tradisi dapat memberikan simbol bagi masyarakatnya, begitu pula tradisi Mipit Pare dapat mencerminkan masyarakat yang senantiasa bersyukur dan senang berbagi sesama manusia.

Tradisi Mipit Pare tidak hanya ada di Desa Mekarsari saja, tradisi ini juga sering dilakukan oleh masyarakat Kasepuhan Ciptagelar Sukabumi. Ritual yang dilaksanakan merupakan medium yang digunakan untuk merefleksikan harapan terhadap apa yang akan dilakukan terkait dengan memanen padi (Aini, 2019). Walaupun nama tradisinya sama, tetapi memiliki makna dan beberapa perbedaan yang menonjol, seperti maknanya tradisi Mipit Pare di Kasepuhan Ciptagelar memiliki makna simbol sebagai permintaan kepada leluhur agar padi yang dihasilkan dari sawahnya melimpah dan tradisinya dilakukan ketika padi berumur 3-4 bulan, sedangkan di Desa Mekarsari maknanya yaitu sebagai tanda syukur karena telah diberikan padi yang berlimpah sehingga siap untuk dipanen, tradisi ini dilakukan sebelum 3 hari padi akan dipanen. Uniknya tradisi Mipit Pare di Kasepuhan Ciptagelar harus menggunakan pakaian khusus, laki-laki menggunakan pakaian serba hitam sedangkan perempuan menggunakan samping dan baju kebaya. Pelaksanaan tradisi Mipit Pare di Kasepuhan Ciptagelar hanya diikuti oleh ketua adat dan pemilik sawah saja, berbeda dengan tradisi Mipit Pare di Kecamatan Cikaum, siapa saja boleh mengikuti tradisi tersebut. Menariknya yang mengikuti tradisi tersebut diwajibkan berjalan kaki dari rumah hingga sawah menyusuri galengan sawah yang sempit dan kotor.

\section{Simpulan dan Saran}

Ritual Mipit Pare merupakan bentuk komunikasi antara masyarakat dengan Leluhurnya. Pelaksanaan ritual Mipit Pare ini dimaksudkan bahwa manusia dan alam memiliki keterikatan yang kuat sehingga harus saling menjaga satu sama lain. Jika manusia menjaga alam maka akan sebaliknya, hal ini bertujuan agar manusia dan alam sama-sama memiliki sinergi untuk mendapatkan keselamatan dari berbagai gangguan dan kerusakan. Setiap tahapan yang berada 
dalam tradisi Mipit Pare masih mengacu kepada tata cara yang diwariskan oleh Leluhur. Tradisi Mipit Pare merupakan cerminan dari masyarakat Desa Mekarsari yang menjunjung tinggi leluhurnya dan mencerminkan manusia yang senang berbagi satu sama lain serta senantiasa bersyukur. Tradisi Mipit Pare memberikan banyak makna simbol bagi masyarakat Desa Mekarsari. Pada proses pemilihan hari dan jam memberikan makna simbol bahwa dalam mengambil keputusan harus berdasarkan ketentuan Leluhur. Sesajen yang dibawa dalam ritual Mipit Pare dipercaya memiliki makna simbol sebagai bentuk terima kasih kepada Leluhur dan Dewi Padi atas apa yang telah diberikan kepada mereka. Pembacaan kidung sambil membakar kemenyan mengandung makna simbol sebagai media untuk memanggil roh Leluhur dan Dewi Padi. Nyembur mengandung makna simbol sebagai penolak bala agar terhindar dari gangguan dan kerusakan. Pembagian bakakak dan nasi uduk mengandung makna simbol berbagi atas rezeki yang dimiliki. Tradisi Mipit Pare merupakan aset budaya yang masih dipertahankan oleh masyarakat Desa Mekarsari ditengah era globalisasi dan perkembangaan kebudayaan asing. Maka dari itu, perlunya dukungan dari pemerintah setempat atau instansi terkait untuk memberi peluang dan ruang bagi masyarakat pendukung kepercayaan tersebut untuk tetap melestarikan tradisi Mipit Pare.

\section{Daftar Rujukan}

Aini, S. N. (2019). Tradisi Mipit Pare di Kasepuhan Ciptagelar. Jurnal Ilmu-Ilmu Ushuluddin, 7(1), 133-150.

Anton, \& Marwati. (2015). Ungkapan Tradisional dalam Upacara Adat Perkawinan Masyarakat Bajo Pulau Bulu Kabupaten Muna Barat. Jurnal Humanika, 3(15), 1-11.

Corytawaty, N., \& Lobodally, A. (2017). Komunikasi Verbal Dan Nonverbal Di Antara Kaum Homoseksual (Studi Deskriptif Pada Pasangan Kaum Homoseksual di Jakarta). Jurnal Cakrawala, 6(2), 277-296.

Elven, S. (2021). Sensus 2020, Penduduk Kabupaten Subang 1,595 Juta Jiwa. Kotasubang.Com. https://www.kotasubang.com/21170/sensus-2020-penduduk-kabupaten-subang-1595juta-jiwa

Hafid, A., \& Raodah, R. (2019). Makna Simbolik Tradisi Ritual Massorong Lopi-Lopi Oleh Masyarakat Mandar Di Tapango, Kabupaten Polman, Provinsi Sulawesi Barat. Walasuji : Jurnal Sejarah Dan Budaya, 10(1), 33-46. https://doi.org/10.36869/wjsb.v10i1.37

Haris, A., \& Amalia, A. (2018). Makna Dan Simbol Dalam Proses Interaksi Sosial (Sebuah Tinjauan Komunikasi). Jurnal Dakwah Risalah, 29(1), 16.

Kusumawati, T. I. (2016). Komunikasi Verbal Dan Nonverbal. Jurnal Pendidikan Dan Konseling, $6(2), 84$.

Muchlisin, R. (2013). Pengertian dan jenis-jenis Makna Kata dalam Bahasa. Kajianpustaka.Com. https://www.kajianpustaka.com/2013/03/pengertian-dan-jenis-jenis-makna-kata.html

Oktavia, F. (2016). Upaya Komunikasi Interpersonal Kepala Desa Borneo Sejahtera Dengan Masyarakat Desa Long Lunuk. Ilmu Komunikasi, 4(1), 239-253.

Raodah. (2009). Makna Simbolis Tradisi Mappaoli Banua Pada Masyarakat Banua Kaiyang Mosso Provinsi Sulawesi Barat. Patanjala, 07(3), 1-73.

Tanujaya, C. (2017). Perancangan Standart Operational Procedure Produksi Pada Perusahaan Coffeein. Jurnal Manajemen Dan Start-Up Bisnis, 2(1), 90-95.

Xiao, A. (2018). Konsep Interaksi Sosial Dalam Komunikasi, Teknologi, Masyarakat. Jurnal Komunika: Jurnal Komunikasi, Media Dan Informatika, 7(2). https://doi.org/10.31504/komunika.v7i2.1486 